\title{
DUBLA CONFIGURARE A SENSULUI ÎN PROVERBELE ROMÂNEȘTI DESPRE HRANĂ. ANALIZĂ DE CAZ: CORPUSUL IULIU ZANNE
}

\section{Contextul și interpretarea sa}

Sub titlul generic Proverbele românilor (din România, Basarabia, Bucovina, Ungaria, Istria și Macedonia) a fost publicată, la trecerea din secolul al XIX-lea către cel de-al XX-lea (între 1895 și 1903), o serie de zece volume masive, alcătuind o lucrare a cărei excepționalitate a fost subliniată în mod constant de-a lungul timpului, de la Precuvântarea la primul volum, semnată de G. Dem. Teodorescu (Zanne 2003 [1895], p. XIV), până la publicațiile recente. Încadrând-o în seria „întâilor tipologii și corpusuri ale folclorului românesc” (Bîrlea 1974, p. 316-335, passim), alături de lucrările unor autori recunoscuți, precum Lazăr Șăineanu, Artur Gorovei și Elena Niculiță-Voronca, Ovidiu Bîrlea descria caracterul monumental al întregii întreprinderi în acești termeni:

„Migala e vădită de numărul mare de publicaţii străbătute pentru excerptarea proverbelor şi zicătorilor: în 1895, acestea însumau 235 de titluri, pentru ca la ultimul volum, din 1903, să ajungă la 294 de titluri. Mai impresionant e numărul colaboratorilor benevoli care crește peste așteptări, de la 191 la început, la 323 în 1899 și la 340 în 1903, adică aproape jumătate din corespondenții lui Hasdeu pentru realizarea dicționarului enciclopedic. Cei mai mulți din acești corespondenți sunt, și la Zanne, învățători, la început din Muntenia și Moldova, pentru ca apoi să se adauge și cei din Transilvania. [...] Printre acești colaboratori se întâlnesc și folcloriști de seamă, consacrați sau debutanți la acea vreme, ca învățătorul Teodor Bălășel, M. Canianu, «publicist», preotul Avram Corcea, învățătorul Petre Danilescu, Artur Gorovei, «magistrat», înv. Mihai Lupescu, G. Madan, învățător, N. Mateescu, E. Sevastos, profesor T. Speranția, învățătorul S. T. Kirileanu și învățătorul Al. Vasiliu” (Bîrlea 1974, p. 324).

La apariția reeditării într-o ediție anastatică a Proverbelor românilor, notam, la rândul meu, că vorbim, de fapt, despre „cel mai extins corpus de texte folclorice românești realizat și publicat deocamdată", pornind de la care o aritmetică elementară ar trebui să contabilizeze circa 8000 de pagini de text tipărit, 18940 de tipuri de proverbe și zicători în primele șapte volume, urmate de alte 4500 de tipuri în volumele al nouălea și al zecelea, precum și 16350 de tipuri de proverbe din colecția de maxime și povățuiri a lui Iordache Golescu, anexată corpusului (Hedeșan 2004, p. 14).

Evident că o privire critică poate descoperi, dincolo de aceste dimensiuni copleșitoare, mai ales pentru o epocă de început a cercetărilor de etnografie și folcloris- 
tică română, și o serie de limite ale corpusului Zanne. Astfel, după cum observă, la limita dintre nota rece și ironie, Ovidiu Bîrlea,

,această colecție are și menirea de a convinge că publicarea tuturor variantelor constituie un lux folcloric, câştigul științific fiind minim, exceptând acela de a demonstra că variabilitatea merge de la nuanța abia perceptibilă la diferențe care vehiculează alt sens, proverbele și zicătorile oferind și variante identice ca formă, posibile dată fiind scurtimea lor şi maxima cizelare din îndelunga circulație" (Bîrlea 1974, p. 326).

În același sens, pot fi invocate și mixajul dintre proverbele de origine orală, obținute în urma informării din lumea satelor, și o serie de expresii memorabile de sorginte literară, ori alăturarea proverbelor propriu-zise cu zicătorile, fără ca autorul să se preocupe în mod aparte de aceste melanjuri. Sintetizând aceste aspecte, Ion Cuceu nota:

„Colecția-corpus a lui Zanne are, de asemenea, numeroase inconsecvențe în privința delimitării categoriei: astfel, selecția materialului este axată pe o viziune învechită asupra speciei; alături de texte autentic populare apar frecvent maxime și aforisme de origine cărturărească certă, prelucrări folclorizate de genul celor ale lui Anton Pann, căruia el i-a dat prea mult credit, sau asemănări extrase din manuscrisul lui Iordache Golescu, toate acestea având puține trăsături comune cu specia propriu-zisă” (Cuceu 2006, p. 28).

Observațiile lui Pavel Ruxăndoiu sunt construite în aceeași logică:

„Eterogenitatea, inclusiv terminologic, se perpetuează și în colecțiile și în dicționarele de mai târziu, cum este, în primul rând, marele corpus alcătuit de Iuliu Zanne [...] în care, în afara resurselor orale, sunt folosite un număr mare de colecții, antologii și alte publicații anterioare" (Ruxăndoiu 2003, p. 12).

Analiza pe care o propun aici nu ignoră nici pregnanța colecției Zanne în folcloristica naţională și, mai ales, nici numeroasele incertitudini în definirea speciei proverbului, pe de o parte, dar și a culturilor folclorice/populare/tradiționale din epoca redactării sale, pe de altă parte. Integrată unei serii de lecturi care urmăresc ${ }^{1}$ dacă și, după caz, cum anume este tratată tema hranei în diferite mari opere ale folcloristicii şi etnografiei românești, această analiză pornește subliniind o prioritate a corpusului de proverbe Zanne, care acordă un capitol aparte, al șaptelea, textelor despre „mâncare și beutură" (Zanne 2004 [1899], p. 437-677; Zanne 2004 [1900], p. 1-192).

Citit prin această fantă a prezentării alimentației și gastronomiei locale în raport cu publicațiile românești de la finalul secolului al XIX-lea și începutul celui de-al XX-lea, corpusul Zanne face notă separată, deoarece el este singurul text care decupează şi denumește curajos o întreagă secțiune a culturii folclorice/populare/tradiționale organizată în jurul hranei. Numeroasele monografii etnografice apărute în deceniile anterioare prin strădaniile lui Simion Florea Marian (Marian 1995 [1890],

\footnotetext{
${ }^{1}$ Analiza de față este parte a cercetărilor desfășurate în cadrul proiectului Colecție digitală a patrimoniului alimentar românesc și transfer spre societate, FOODie, PNCDI III, Programme 2, Subprogramme 2.1., PED 569.
} 
Marian 1995a [1892], Marian 1995b [1892], Marian 2001 [1899-1901]), corpusul de credințe al Elenei Niculiță-Voronca (Niculiță-Voronca 1998 [1903]), publicat sincron cu volumele de proverbe ale lui Zanne, mai apoi monografiile tematice ale lui Tudor Pamfile (Pamfile [1997] 1910-1914) cuprind destul de multe informații despre hrană, dar le plasează mereu în alte contexte, fie ca părți marginale ale unor manifestări rituale sau festive, fie, mai ales în cazul textelor narative, ca probe pentru numeroase și foarte variate alte teme, de la facerea lumii la imaginarul personajelor mitologice.

Urmărit per se, corpusul Zanne conține proverbe organizate în 23 de capitole, adică:

„I. Natura fisică (astre, anotimpuri, timp, variațiuni climaterice, sărbători, an, zile, ceasuri), II. Natura fisică (elemente, pământ, metaluri, pietre, plante, poame, cultura pământului), III. Despre animale (păsări, patrupede, insecte, pești), IV. Omul și organele sale (omul în genere, bărbat, femeie, copii, organe, membre), V. Despre viața fisică (trupul omului, stările, facultățile și mișcările sale, viață, moarte, informități, boale, mișcări, cele cinci simțuri, mișcări, vis), VI. Despre viața fisică (obiceiuri, îmbrăcăminte, case și clădiri diverse, gospodăria casei), VII. Despre viața fisică (mâncare, beutură), VIII. Despre viața socială (vecin, prietin, cercetări, asociațiuni), IX. Despre viața socială (stări sociale, dregătorii, titluri, război, jocuri, petreceri, arme, instrumente de muzică), X. Despre viața socială (justiție, legi, învățătură, negustorie, călătorie, negustorii, unelte), XI. Proverbe istorice (țări, popoare, orașe, sate, localităti diverse, nume proprii), XII. Credinți, eresuri, obiceiuri, XIII. Despre viața intelectuală și morală (sufletul și facultățile sale), XIV. Despre viața intelectuală și morală (conștiința și inima), XV. Despre viața intelectuală și morală (calități și virtuți), XVI. Despre viața intelectuală şi morală (Defecte, viciuri și crime), XVII. Povețe şi opriri, maxime, sentințe și pilde filosofești, XVIII. Maxime extrase din diferiți autori români, XIX. Maximele lui Iordache Golescu, XX. Asemănările in literatura poporală, XXI. Asemănările lui Iordache Golescu, XXII. O seamă de idiotisme și locuțiuni, XXIII. Cimilituri" (Zanne 2003 [1895], p. XLIV-XLV).

Lăsând deoparte secțiunile dedicate restituirii contribuției lui Iordache Golescu, precum și cele alocate unor categorii textuale proxime proverbelor, dar pe care autorul le include, totuși, în corpusul său (asemănări, cimilituri, povețe, maxime, sentințe, pilde etc.), rezultă că Zanne propune un sistem de ierarhizare a universului de credințe populare care este reflectat prin proverbe în două secțiuni principale: natura fizică, pe de o parte, și omul ca ființă complexă, pe de alta. În ceea ce privește reprezentarea antropologică, omul este privit și exprimat ca o realitate concretă, „fisică”, apoi ca prezență într-un angrenaj social, respectiv ca loc de manifestare a unor cunoștințe, convingeri și sentimente. În raport cu această structură ierarhică, în viziunea lui Zanne, hrana și pandantul său, băutura, se raportează la sfera antropologică în componenta sa naturală. Evident că, dinspre prezent, este greu de acceptat că un corpus de texte care numește ospitalitatea cu formula ,,a primi (pe cineva) cu pâine și sare”, dragostea cu ,a se sătura dintr-un blid” ori despărțirea 
prin „pâine și sare cu (cineva) n-oi mai mânca” exprimă un sector al realității materiale, și nu al celei sociale, însă suntem la începutul secolului al douăzecilea, când toate construcțiile sunt de făcut, și pe terenul culturii folclorice românești.

\section{7 de proverbe despre hrană și băutură}

Capitolul al șaptelea al corpusului de proverbe al lui Zanne este unul consistent, configurat în jurul cuvintelor-cheie „mâncare” și „beutură”. Se conturează, aici, un corpus textual extins, în care au fost antologate 1437 de proverbe (cuprinse între tipurile 8055-9492), în majoritatea cazurilor cu numeroase variante regionale, istorice sau stilistice. Așa cum am arătat și mai înainte, uneori variantele oferite sunt pasaje din cărțile populare sau din texte de tip auctorial, bunăoară sunt preluate din Anton Pann, însă pentru analiza de față mă voi dezinteresa în mod deliberat de această inconsecvență generică, fără a vicia astfel sensul general al analizei, întrucât, indiferent de proveniență, aceste expresii fac parte din ceea ce poate fi considerat imaginarul românesc al expresiilor active referitoare la hrană, de la cumpăna secolelor al XIX-lea și al XX-lea.

Aceste proverbe se repartizează în funcție de 360 de cuvinte-titlu care se referă la hrană, inclusiv la băuturi, dintre care, în 301 cazuri, exemplele sunt redate in extenso. 59 de intrări sunt rezervate fie unor sinonime regionale (de ex. birtl crâșmă, zeamă/zamă, cauc/şofei), fie unor termeni care apar în relație cu alte cuvinte cu funcție de nucleu semantic (de ex. a adăpa este pus în relație cu apă, butilcă este pus în relație cu vin), fie unor unităţi care au fost introduse deja în capitole anterioare, fiind reprezentative și pentru alte criterii de clasificare (de ex. cireașă, prună sunt prezente în capitolul despre plante).

Ce spun despre alimentația românilor aceste texte, desfășurate pe aproape 400 de pagini tipărite? La un prim nivel, de suprafață, o caracterizare sintetică poate fi preluată, tale quale, din eseurile lui Petru Ursache despre tradițiile gastronomice românești. După acest etnolog,

„paremiologia (proverbele şi zicătorile) îşi asumă latura etnosofică a științei alimentației, reluând în forme proprii de gândire temele cotidiene. [...] [Proverbele] îndeplinesc funcția de învățăminte morale și de comportament și stau la îndemâna unor specialiști orali ai vorbelor de duh. Pâinea, laptele, ouăle, fructele, legumele sunt evocate ca pretexte de meditație, de caracterologie, uneori cu rigoarea reflexivă râvnită de cei mai cultivați filosofi” (Ursache 2014, p. 40).

Urmând, însă, pas cu pas, textele proverbelor, trebuie subliniată diversitatea fascinantă a acestora, proximitatea semantică a unora, dar și singularitatea altora, caracterul indicativ al unor texte ori figuralitatea altora. O selecție minimală ( 25 de exemple) din amplul corpus discutat poate funcționa ca o foarte sugestivă imagine holografică a complexității acestui imaginar sapiențial al hranei românești. Astfel: Unul mănâncă aguridă și la altul $i$ se strepezesc dinții (Zanne 2004 [1899], p. 438), N-are după ce be apă și el se scobește în măsele (ibidem, p. 448), Multe 
spune, dar bob mănâncă (ibidem, p. 480), S-a-mpuțit brânza (ibidem, p. 490), Trei ape în chiseliță (ibidem, p. 521), Carne fără ciolan nu se poate (ibidem, p. 500), Râde ciob de oală spartă (ibidem, p. 524), S-a întâlnit foamea cu setea (ibidem, p. 562), Laptele, și a vacii frumoase, și a vacii proaste, face coraslă (ibidem, p. 587), Mămăliga-i stâlpul casei, pâinea-i cinstea mesei (ibidem, p. 609), A mânca fript (pe cineva) (ibidem, p. 635), La mâncare lup, la învățătură butuc (ibidem, p. 638), Unde nu-ți fierbe oala, nu-ți băga lingura (Zanne, 2004 [1900], p. 17), Faptele, faptele, / Nu oala cu laptele (ibidem, p. 20), Mai dulce oțetul fără plată decât mierea cu plată (ibidem, p. 30), Păhăruțu-i cât un cui / Când îl pui la gură, nu-i (ibidem, p. 39), Dacă nu e colac, e bună și pânea (ibidem, p. 43), Cine a mâncat papară / Știe dulce-i ori amară (ibidem, p. 64), Se amestecă ca pătrunjelul în toate bucatele (ibidem, p. 70), Nu număra foile la plăcinte (ibidem, p. 89), Și sătul, și cu punga plină nu se poate (ibidem, p.113), Șofran nu poți găsi în orice băcănie (ibidem, p. 121), Cine se amestecă în tărâțe îl mănâncă porcii (ibidem, p. 136), Mult tocat, puțin mâncat (ibidem, p. 151), A jurat pe apă că nu bea vin (ibidem, p. 180).

Desigur, caracterizările generale făcute proverbelor de cercetătorii acestei specii sunt utile și pentru apropierea de rețelele semantice în jurul cărora gravitează corpusul tematic al hranei. „Proverbul e unul dintre cele mai vechi și mai tari depozite ale experienței umane înnobilate de fantezie" (Papadima 1968, p. 602), el ,,[...] concentrează în forme succinte înțelepciunea de veacuri a unui popor, experiența lui socială, concepția lui filosofică despre viață, moarte, natură, suferință, fericire, soartă, muncă" (Eretescu 2004, p. 228). În mod concret, în cazul proverbelor românești despre hrană, inclusiv pornind de la selecția de texte de mai sus, „experiența umană" și socială pare să se articuleze în jurul câtorva unități semantice fundamentale, dintre care mentionez:

Acțiuni și stări: a bea (Zanne 2004 [1899], p. 451-459) și, apoi, beat (ibidem, p. 460-466), beție (ibidem, p. 467-475), beutură (ibidem, p. 475-477), bețiv (ibidem, p. 470-475), a mânca (ibidem, p. 615-636) și, apoi, mâncare (ibidem, p. 636-642) masă (ibidem, p. 646-657), dar și hrană, a hrăni (ibidem, p. 576-577) şi, în mod antonimic, foame (ibidem, p. 556-563) etc.

Gusturi: acru (ibidem, p. 437-438) și, apoi, oțet (Zanne 2004 [1900], p. 30-33) și apoi aguridă (Zanne 2004 [1899], p. 438-439), amar (ibidem, p. 440-442), dulce (ibidem, p. 538-549) și, apoi, dulceață (ibidem, p. 540-541), gust (ibidem, p. 571-573) etc.

Ingrediente principale: apă (ibidem, p. 442-449), carne (ibidem, p. 507-510), lapte (ibidem, p. 587-591), miere (ibidem, p. 663-677), os (Zanne 2004 [1900], p. 27-29), ou (ibidem, p. 34-38), tărâțe (ibidem, p. 136-144) etc.

Maniere de preparare: a coace (Zanne 2004 [1899], p. 529-530), a fierbe (ibidem, p. 550) și, apoi, fiert (ibidem, p. 550-551), frământare (ibidem, p. 564565), a frige (ibidem, p. 567) și, apoi, fript (ibidem, p. 567) și, apoi, friptură (ibidem) etc. 
Feluri de mâncare principale: borș (ibidem, p. 480-482), brânză (ibidem, p. 484-492), caș (ibidem, p. 511-513), chiseliță (ibidem, p. 530-522), clisă (ibidem, p. 528-529) și, apoi, slănină (ibidem, p. 121-126), mălai (ibidem, p. 597603) și, apoi, mămăligă (ibidem, p. 603-615), pâne (Zanne 2004 [1900], p. 43-64) și, apoi, pită (ibidem, p. 80-85), păsat (ibidem, p. 66-69), plăcintă (ibidem, p. 8593), unt (ibidem, p. 160-162) și, apoi, unt-de-lemn (ibidem, p. 162-164) şi, apoi, untură (ibidem, p. 164-167), vin (ibidem, p. 176-190) etc.

Condimente: ce(a)pă (Zanne 2004 [1899], p. 517-519), pătrunjel (Zanne 2004 [1900], p. 70), piper (ibidem, p.75-80), sare (ibidem, p. 105-110), șofran (ibidem, p. 125), usturoi (ibidem, p. 167-170) etc.

Ustensile necesare gătitului: blid (Zanne 2004 [1899], p. 477-479), capac (ibidem, p. 501-502), farfurie (ibidem, p. 547-548), hârb (ibidem, p. 573-576), o(a) lă (Zanne 2004 [1900], p. 5-26), pahar (ibidem, p. 38-42), strachină (ibidem, p. 129-131), ulcior (ibidem, p. 158-160) și, apoi, urcior (ibidem, p. 165-166) etc.

(Re)structurate astfel, unitățile lexicale în funcție de care Zanne a organizat suma de proverbe avute la dispoziție restituie un univers tradițional destul de coerent, unde se folosesc în mod preferențial anumite ingrediente culinare, unde se recurge la practici de a găti bine-cunoscute, unde se obișnuiește să se pregătească feluri de mâncare tradiționale, sunt cunoscute și valorizate anumite gusturi, iar acestea pot fi obținute prin utilizarea unei serii iarăși finite de condimente, un spațiu unde se folosesc ustensile (vase) clar stabilite pentru prepararea mâncării. Organizarea colecției, cu aranjarea alfabetică a intrărilor, a ocultat, pentru multă vreme, acest adevărat desen din covor care se poate observa notând reliefurile, repetițiile și mai ales construind sensurile prin raportare la realitate.

Schița pe care o restitui aici pornind de la suma foarte amplă de proverbe din corpusul lui Zanne amintește insistent de o lucrare care va vedea lumina tiparului nedrept de târziu, doar în anul 2000, în pofida transmiterii sale către Academia Română în anul 1916, cartea lui Mihai Lupescu, Din bucătăria țăranului român. Chiar dacă informațiile de care dispun în momentul redactării acestei analize nu-mi permit să formulez opinii despre felul în care cei doi folcloriști, Iuliu Zanne şi Mihai Lupescu, au interacționat, despre ideile pe care și le-au comunicat, nu pot să nu observ că Mihai Lupescu se numără între corespondenții lui Zanne pentru realizarea monumentalului său corpus (Zanne 2004 [1899], p. XXII, Zanne 2004 [1900], p. XIX). Totodată, nu pot nici să ignor că principalele capitole din cartea lui Mihai Lupescu urmăresc ingredientele alimentare cele mai reprezentative, felurile de mâncare cunoscute în diferite regiuni, instrumentarul din bucătăriile țărănești (Lupescu 2000 [1916], p. 223). Mai mult decât atât, nu pot nici să nu notez că există și cazuri (este drept că acestea nu sunt numeroase) în care textul lui Zanne și cel al lui Lupescu sunt extrem de apropiate. Astfel, cuvântul-intrare mămăligă (Zanne 2004 [1899], p. 603) nu este unul care să introducă pur și simplu proverbe, ci este, de fapt, o mică prezentare a acestui fel de mâncare atât de important în alimentația țărănească. Lectura sa în paralel cu paginile dedicate aceleiași la Lupescu 
(Lupescu 2000 [1916], p. 127-129) poate funcționa ca o adevărată cheie a colaborării apropiate a celor doi.

Dincolo de această structură a universului culinar românesc care poate fi descoperită grație corpusului de proverbe publicat de Zanne, fiecare dintre nodurile semantice și, uneori, chiar fiecare dintre cuvintele de intrare permite deschiderea unui întreg univers complex și sofisticat, interesant în sine însuși pentru numeroasele interpretări pe care le permite. Astfel, bunăoară, este evident că, într-o ierarhie românească a gusturilor, dulcele (cu ingredientele care îl pot genera, mierea şi zahărul) ocupă o poziție privilegiată, în vreme ce amarul este chiar opusul său, fiindcă omul are un dulce și un amar (Zanne 2004 [1899], p. 540), după cum unii pot fi dulci la limbă, amari la inimă (ibidem, p. 539). Tot despre o ierarhie simbolică este vorba și în cazul ingredientelor folosite pentru prepararea hranei. Astfel, dacă apa nu este bună nici în cizme (ibidem, p. 442), laptele este mereu dorit, după cum spune proverbul, umblă ca mâta pe lângă laptele fierbinte (ibidem, p. 587). Tot astfel, carnea face carne (ibidem, p. 510), în vreme ce solicitanții de beneficii minore așteaptă un os de ros (Zanne 2004 [1900], p. 29).

Cele mai complexe sunt, însă, proverbele care includ cuvinte denominând alimente preparate sau feluri de mâncare. $O$ primă lectură poate identifica adevărate poziționări ierarhice ale alimentelor: cozonacul și plăcintele sunt, astfel, superioare pâiniil/pitei, aceasta fiind superioară mămăligii/mălaiului. Este revelatoare, în acest sens, o serie de tipul: noi n-avem pâine și câinii umblă cu colaci în coadă (Zanne 2004 [1899], p. 533), nu se mănâncă în toate zilele plăcinte (Zanne 2004 [1900], p. 91), bună e și mămăliga, când ne lipsește pâinea (Zanne 2004 [1899], p. 609), mămăliga-i stâlpul casei, pâinea-i cinstea mesei (ibidem, p. 609), vai-vai-vai de cine n-are mălai (ibidem, p. 588).

Uneori, alimentele și felurile de mâncare sau băutură participă la serii valorice diferite. Astfel, braga, de exemplu, este prezentă într-un mic număr de proverbe, uneori cu valorizare discret pozitivă, la lipsă de inghețată, braga ne răcorește (ibidem, p. 483), alteori intens negativă, ca braga în ziua de Paști (ibidem, p. 483).

În cazul alimentelor foarte importante, pletora semantică este una impresionantă și adesea cu sensuri care pot fi contradictorii. Practic, fiecare din aceste unităţi de sens deschide un univers propriu, cu referințe culturale proprii și mizând pe structuri figurative aparte. Un bun exemplu în acest sens este cel al brânzei (ibidem, p. 484-492), cu care sunt consemnate mai multe proverbe: când e brânzăa, nu-i bărbânță; ai și tu puțină brânză la putină și crezi, acum, că ai cășărie; brânza o mâncat-o câinii, dar găleata-i de față; brânza de capră strică și pe cea de oaie; brânză bună în burduf de câine; de-am avea brânzăa, după cum n-avem pâine, bună apă de papară; mănâncă brânză cu mămăligă goală; vaci n-avem, brânză mâncăm; burduf de brânză în seama câinilor; brânză de iepuri; s-a băgat brânza- $n$ putină; a nu fi bun de nicio brânză; nu e nicio brânză de el; a nu face brânză cu cineva; s-a umplut de brânză ca broasca de păr; s-a împuțit brânza; s-alege brânza din zer; $i$-a cam ieșit brânza din barbăa pune brânza în sticlă și întinge pe din afară; zgârie brânză; brânză- $n$ bete. Este greu de înțeles un asemenea set de texte 
fără invocarea experiențelor culturale ale unor populații specializate în creșterea animalelor și prelucrarea laptelui. Indiferent de sensurile concrete ale fiecăruia dintre proverbele citate mai sus, brânza este pozitivă în sine, mai ales dacă este brânză de oaie, de vacă și obținută cu răbdare, prin muncă (se alege brânza din zer). Ea este incompatibilă cu melanjul nefiresc (brânza de capră, de iepuri, în burduf de câine), iar aceste expresii frizează, de fapt, mențiunea indirectă a unor adevărate tabu-uri alimentare, capra, iepurele și, desigur, câinele, numărându-se între mamiferele a căror carne se află sub diferite grade de interdicție, de la nerecomandare la interdicția fermă. Brânza este asociată și cu tratamentul nepotrivit (se-mpute brânza). Totodată, ea rămâne mai degrabă alimentul modestiei (se mănâncă cu mămăligă goală, iar puțină brânză în putină nu înseamnă și existența unei căşării).

Studiul proverbelor despre hrană și băuturi argumentează reformularea unei chestiuni esențiale referitoare la această specie și, totodată, o lasă deschisă:

„[...] de ce găsim, în lumea proverbului, îndreptăţire pentru aproape tot ce se petrece sau măcar se bagă în seamă, fie între oameni, fie în lumea largă a animalelor, a ierburilor, a stihiilor? De ce se găsesc în lumea proverbelor acele nostime perechi de proverbe prin care și un lucru, dar și absolut contrariul său, sunt îndreptățite printr-o vorbă, dacă nu adâncă, măcar de duh?” (Papadima 1968, p. 596).

\section{Dubla configurare a sensului în proverbe}

Interpretările propuse mai sus au operat în mod exclusiv pe nivelul superficial, lingvistic, al proverbelor. Astfel, comentariul a urmat maniera de organizare a textelor în corpusul lui Zanne, în sensul în care a urmărit construcția discursivă a universului gastronomic tradițional, așa cum poate fi ea restituită prin genul sapiențial.

Totuși, proverbele nu sunt simple expresii stereotipe, care să reflecte în mod univoc realitatea, în pofida numeroaselor analize, care insistă doar asupra structurilor lor formale (Tabarcea 1982, Negreanu 1983). După cum observă teoreticienii lor, acestea sunt „forme de creație populară, forme de cunoaștere primitivă sau populară și expresii lingvistice" (Pop, Ruxăndoiu 1990, p. 180). Ele formulează judecăți, având, ,deci, un echivalent semnificativ pe care îl simbolizează și care e traductibil în parafraze mai largi. Acest echivalent semnificativ reprezintă un consens etic general, valabil pentru un număr foarte mare de oameni” (ibidem, p. 183).

Ideea este că:

„paremiologii au fost intrigați de complexitatea structurală a proverbelor. [...] Dincolo de aparenta lor simplitate, proverbele și expresiile proverbiale sunt departe de a fi astfel. În primul rând, ele sunt fenomene de limbaj similare cu unitățile frazeologice ordinare; apoi, ele sunt unități logice (supoziții și concluzii); în același timp, ele sunt miniaturi artistice care reflectă viața reală în forma unei miniaturi grafice. Tripla natură a proverbelor determină o triplă abordare, iar ele trebuie să fie tratate ca fenomene de limbă, ca fenomene filosofice și ca fapte de folclor" (Permyakov 1979, p. 9).

Particularizând aceste observații cu caracter general la situația proverbelor despre „mâncare și beutură” din corpusul lui Zanne, voi observa și că, în majoritatea cazuri- 
lor, fiecare proverb consemnat este urmat de consemnarea unei semnificații externe a lui, care ține, în general, de sfera socială și morală. Astfel, bunăoară, dacă mă refer doar la cele 25 de proverbe alese spre exemplificare mai sus, trebuie să observ că acestea sunt dublate de semnificații externe, după cum urmează:

Unul mănâncă aguridă și la altul $i$ se strepezesc dinții/,„unii greșesc și alții pătimesc" (Zanne 2004 [1899], p. 438), N-are după ce be apă și el se scobește în măsele/,e sărac și mândru” (ibidem, p. 448), Multe spune, dar bob mănâncă/1. „este însărcinată”; 2. „minte” (ibidem, p. 480), S-a-mpuţit brânza/,,a se strica prietenia" (ibidem, p. 490), Trei ape în chiseliță/,,adică rudeniile de departe, încât nu se mai socotesc de rudă” (ibidem, p. 521), Carne färă ciolan nu se poate/,nu e om fără cusur, câsștig fără pagubă, plăcere fără supărare" (ibidem, p. 509), Râde ciob de oală spartă (ibidem, p. 524), S-a întâlnit foamea cu setea/1. „se zice mai mult pentru soți, când amândoi sunt săraci”; 2. „Rareori, când doi nevoiași se întovărășesc pentru a face oarece" (ibidem, p. 562), Laptele, și a vacii frumoase, și a vacii proaste, face coraslăl,,boierii, ca și țăranii, fac greșeli și fapte rele” (ibidem, p. 587), Mămăliga-i stâlpul casei, pâinea-i cinstea mesei/,pentru boieri și țărani”" (ibidem, p. 609), A mânca fript (pe cineva)/,,a-1 învinge, a-1 nimici, a-1 pierde" (ibidem, p. 635), La mâncare lup, la învățătură butuc/,pentru cel leneș la învățătură” (ibidem, p. 638), Unde nu-ți fierbe oala, nu-ți băga lingural,,adică să nu ne amestecăm unde n-avem treabă, unde nu e slobod" (Zanne 2004 [1900], p. 17), Faptele, faptele, / Nu oala cu laptele/,omul se judecă după faptele lui” (ibidem, p. 20), Mai dulce oțetul fără plată decât mierea cu plată/,,se zice pentru cei ce n-au cu ce cumpăra, cum și pentru cei zgârciți” (ibidem, p. 30), Păhăruțu-i cât un cui, / Când îl pui la gură, nu-i ,zice omul căruia-i place să bea bine” (ibidem, p.39), Dacă nu e colac, e bună și pânea/,,în lipsa unui lucru bun, ne mulțumim și cu altul mai prost" (ibidem, p. 43), Cine a mâncat papară/Știe dulce-i ori amară/,,tot pățitu-i priceput" (ibidem, p. 64), Se amestecă ca pătrunjelul în toate bucatele/,,se amestecă în toate” (ibidem, p. 70), Nu număra foile la plăcinte/1. „,nu mai pierde vreme și apucă-te de treabă”; 2. „taci și mănâncă” (ibidem, p. 89), Și sătul, și cu punga plină nu se poate/,,trebuie să dai ca să dobândești; se zice celui care vrea să-și facă interesele și să nu-1 coste" (ibidem, p.113), Șofran nu poți găsi în orice băcănie/,,adică lucruri deosebite la cei proști” (ibidem, p. 125), Cine se amestecă în tărâțe îl mănâncă porciil/,omul cuminte e cel care-și vede de treabă și care nu se amestecă în lucruri care nu sunt pentru el" (ibidem, p. 136), Mult tocat, puțin mâncat/,,se zice pentru cei care mult muncesc, dar puțin li se plătește" (ibidem, p. 151), A jurat pe apă că nu bea vin/,o vorbă mincinoasă” (ibidem, p. 180).

La acest nivel neexprimat expressis verbis, însă subînțeles, proverbele selectate se referă la greșeală, suferință, mândrie deșartă, minciună, prietenie, supărare, sărăcie, lene, hărnicie, zgârcenie, cumpătare, indiscreție, meschinărie. Alegerea altor exemple ar conduce la generarea unei liste și mai ample de trăsături morale și de aspecte sociale evocate prin proverbe. De altfel, această dublare a formei cu sensuri morale, neexprimate, însă subînțelese, subminează, după părerea mea, situarea ca- 
tegoriei proverbelor despre „mâncare și beutură” în categoria generale a „naturii fisice", a domeniului natural, iar nu în domeniul social.

Constatând existența celor două niveluri ale proverbelor, unul lingvistic, în care este vorba despre hrană, și unul semantic, în care se subînțeleg informații morale, mă întreb care sunt resorturile care au condus, în timp, la stabilirea relaţiilor dintre aceste forme și aceste sensuri, dincoace de ceea ce teoreticienii proverbului numesc „contextul genetic” (Ruxăndoiu 2003, p. 43). Evident, trebuie notat și că sensurile morale, absente în formulare, pot fi identificate fără nicio problemă de vorbitorii interni unei comunități, rămânând însă inaccesibile străinilor, care recepționează exclusiv varianta lingvistică, superficială, a textului, fără ca această lectură liniară să conducă la vicierea sensului general al textului. Altfel spus, chestiunea care se pune ține de descrierea celor două nivele ale proverbului și, implicit, ale comunicării prin intermediul acestui gen. Referințele la hrană sunt evidente, iar pentru o parte dintre receptori, cei din interiorul comunității, sunt subînţelese în mod direct și semnificatiile morale.

Pe de altă parte, stratul de suprafață are o independență care nu e de neglijat, în măsura în care el evocă o lume, în cazul de față aceea a universului alimentar și a rigorilor sale. Aici, pe nivelul de suprafață, se află, difuze, informații despre alimentele prețioase și cele nesemnificative, despre felurile de hrană importante ori marginale, despre anumite maniere de preparare și despre virtuțile ori viciile inerente acestor practici. Sunt tentată să spun și că semnificațiile ascunse, cele morale, pe care le induc proverbele, pot fi înțelese nu doar grație unei învățări comunitare care stabilește relații între forme și înțelesuri și care, de la un moment dat, devin nemotivate, ci și datorită forței expresive a proverbului, care acroșează anumite cunoștinţe comunitare difuze. Altfel spus, proverbele exprimă un univers, trimit la un sistem moral, dar mai ales păstrează în ele o sumă de cunoștințe neexprimate expressis verbis, ci doar figural, de către comunitate.

Ceea ce numesc dubla configurare a sensului în proverbe este chiar această orientare pe două direcții a semnificației: un strat in paesentia este îndeobște considerat figural și asociat cu o semnificație morală, dar, mai ales, același strat in praesentia evocă o lume cu rânduieli și ierarhii, despre care nu se vorbește niciodată în termeni proprii, care trebuie să fie mereu dedusă pentru menținerea funcționalității unei culturi. Sunt tentată să asociez această a doua direcție de configurare a sensului, această niciodată formulată expressis verbis cunoaștere-stricto sensu a celor referitoare la hrană-cu ceea ce Permyakov numea „componenta folclorică” a proverbului (Permyakov, 1979, p. 9), fără a-i dedica, însă, pagini separate în foarte comprehensiva sa lucrare. Altfel spus, proverbul merită să fie privit ca expresie, ca sens asociat (moral sau, mai general, filosofic) și mai ales ca univers cultural neexprimat tale quale, dar care poate fi restituit prin reflecția asupra sa. 


\section{ABREVIERI BIBLIOGRAFICE}

Bîrlea 1974 = Ovidiu Bîrlea, Istoria folcloristicii românești, București, Editura Enciclopedică Română, 1974.

Cuceu 2006 = Ion Cuceu, Dicționarul proverbelor românești. 7777 texte din Dicționarul tezaur al paremiologiei românești, Chișinău, Litera Internațional, 2006.

Eretescu 2004 = Constantin Eretescu, Folclorul literar al românilor. O privire contemporană, București, Compania, 2004

Hedeșan 2004 = Un proiect național, în „România literară”, 2004, nr. 12, p. 14.

Lupescu 2000 [1916] = Mihai Lupescu, Din bucătăria țăranului român. Prefață de Radu Anton Roman. Studiu introductiv și bibliografie Maria Rafailă. Postfață de Antoaneta Olteanu, București, Paideia, 2000.

Marian 1995 [1890] = Simion Florea Marian, Nunta la români. Ediție critică de Teofil Teaha, Ioan Şerb, Ioan Ilișiu, București, „Grai și Suflet-Cultura Națională”, 1995.

Marian 1995a [1892] = Simion Florea Marian, Nașterea la români. Ediție critică de Teofil Teaha, Ioan Șerb, Ioan Ilișiu, București, „Grai și Suflet-Cultura Națională”, 1995.

Marian 1995b [1892] = Simion Florea Marian, Inmormântarea la români. Ediție critică de Teofil Teaha, Ioan Șerb, Ioan Ilișiu, București, „Grai și Suflet-Cultura Națională”, 1995.

Marian 2001 [1899-1901] = Simion Florea Marian, Sărbătorile la români, vol. I-III. Ediție îngrijită și introducere de Iordan Datcu, București, „Grai și Suflet-Cultura Națională”, 2001.

Negreanu 1983 = Constantin Negreanu, Structura proverbelor românești, București, Editura Științifică și Enciclopedică, 1983.

Niculiță-Voronca 1998 [1903] = Elena Niculiță-Voronca, Datinele şi credințele poporului român adunate și așezate în ordine alfabetică. Ediție îngrijită de Victor Durnea. Studiu introductiv de Lucia Berdan, Iași, Polirom, 1998.

Pamfile 1997 [1910-1914] = Tudor Pamfile, Sărbătorile la români. Studiu etnografic. Ediție şi introducere de Iordan Datcu, București, Saeculum I.O., 1997.

Papadima 1968 = Ovidiu Papadima, Proverbul, ca formă de îțelepciune, în Literatură populară română. Din istoria și poetica ei, București, Editura pentru Literatură, 1968, p. 596-604.

Permyakov 1979 = G. L. Permyakov, From Proverb to Folk-Tale. Notes on the general theory of cliché [1968-ed. rusă], Moscow, 1979.

Pop, Ruxăndoiu 1990 = Mihai Pop, Pavel Ruxăndoiu, Folclor literar românesc, București, Editura Didactică și Pedagogică, 1990.

Ruxăndoiu 2003 = Pavel Ruxăndoiu, Proverb și context, București, Editura Universității din București, 2003.

Tabarcea 1982 = Cezar Tabarcea, Poetica proverbului, București, Minerva, 1982.

Ursache 2014 = Petru Ursache, Gastrosofia sau bucătăria vie, Cluj, Eikon, 2014.

Zanne 2003 [1895] = Iuliu A. Zanne, Proverbele românilor din România, Basarabia, Bucovina. Ungaria, Istria și Macedonia, vol. I. Ediție îngrijită de Mugur Vasiliu, cu o prefață de Nicolae Constantinescu, București, Asociaţia pentru Cultură şi Ortodoxie SCARA, 2003.

Zanne 2004 [1899] = Iuliu A. Zanne, Proverbele românilor din România, Basarabia, Bucovina. Ungaria, Istria și Macedonia, vol. III. Ediție îngrijită de Mugur Vasiliu, cu o prefață de Nicolae Constantinescu, București, Asociația pentru Cultură și Ortodoxie SCARA, 2004.

Zanne 2004 [1900] = Iuliu A. Zanne, Proverbele românilor din România, Basarabia, Bucovina. Ungaria, Istria și Macedonia, vol. IV. Cu o prefață de Dan Toma Dulciu, București, Asociația pentru Cultură și Ortodoxie SCARA, 2004. 


\title{
DOUBLE CONFIGURATION OF MEANING IN ROMANIAN PROVERBS ABOUT FOOD. A CASE ANALYSIS: IULIU ZANNE'S CORPUS (Abstract)
}

This article presents and proposes an analysis of Romanian proverbs which were published in the Chapter VII, about physical reality-Food and drinks, part of a monumental collection Romanian's Proverbs (ten volumes edited by Iuliu Zanne, 1897-1903). These are 1437 proverbs which refer to the 360 semantic units from the gastronomic domain. There are identified a few aspects which these proverbs focus on: the activities and the states related with food (to eat, to drink, to be full, to be hungry etc.), the tastes (sour, bitter, salty, sweet), the typical manners to cook traditional food (to boil, to bake etc.), the main ingredients for foods (meat, milk, eggs, fish, cheese, different fruits, different vegetables etc.), local traditional dishes (bread-pâine, pită, polenta-mălai, mămăligă, wine-vin etc.), the main spices. The analysis underlines the double configuration of meaning in this category of proverbs: each proverb has a social and cultural accepted meaning, in direct relation with community's specific values and rules. In the same time, the analyzed corpus suggests foods hierarchies, internal values and symbolic meanings of different dishes.

Cuvinte-cheie: etnologie românească, proverb, hrană tradițională, Iuliu Zanne, dubla configurare a sensului în proverbe.

Keywords: Romanian ethnology, proverbs, traditional food, Iuliu Zanne, the double configuration of meaning in proverbs.

\author{
Universitatea de Vest din Timișoara \\ Timișoara, Bd. Vasile Pârvan, 4 \\ otilia.hedesan@e-uvt.ro
}

